\title{
Investigation of Keto-enol Tautomers during the Synthesis of Aryl-bis (2-hydroxy-1-naphthyl)Methanes
}

\author{
PAPIA DUTTA, MRINAL SAIKIA, RASHMI JYOTI DAS and RULI BORAH* \\ Department of Chemical Sciences, Tezpur University, Napaam 784028, Tezpur, Assam, India \\ e-mail: ruli@tezu.ernet.in
}

MS received 8 April 2014; revised 06 September 2014; accepted 16 September 2014

\begin{abstract}
This study investigated the existence of keto-enol tautomers for the first time during the synthesis of aryl-bis(2-hydroxy-1-naphthyl)methane from 2-naphthol and $p$-tolualdehyde or 4-chlorobenzaldehyde in methanol using $\mathrm{CuSO}_{4} .5 \mathrm{H}_{2} \mathrm{O}$ as catalyst under reflux condition. The exclusive formation of aryl-bis(2-hydroxy1-naphthyl)methanes was observed in dichloromethane at room temperature in the presence of $\mathrm{BF}_{3} . \mathrm{OEt}_{2} / \mathrm{AcOH}$ as catalyst. The keto products were isolated and characterized by ${ }^{1} \mathrm{H} N M R,{ }^{13} \mathrm{C} N \mathrm{NR}, \mathrm{COSY}$ and DEPTspectra.
\end{abstract}

Keywords. Aryl-bis(2-hydroxy-1-naphthyl)methanes; keto-enol tautomer; $\mathrm{CuSO}_{4} \cdot 5 \mathrm{H}_{2} \mathrm{O} ; . \mathrm{BF}_{3} . \mathrm{OEt}_{2} / \mathrm{acetic}$ acid.

\section{Introduction}

Dibenzoxanthene derivatives (5) are prepared by acid catalyzed cyclocondensation of 2-naphthol with aldehydes via the formation of tautomeric mixture of intermediates, aryl-bis (2-hydroxy-1-naphthyl)methane (4) and its keto isomer (3) (scheme 1). This compound has broad applications in medicinal chemistry, ${ }^{1}$ material science, ${ }^{2,3}$ photodynamic therapy and laser technologies. ${ }^{4}$

The intermediates aryl-bis(2-hydroxy-1-naphthyl) methane (4) also known as aryl-bisnaphthol constitute a non-steroidal class of medicaments with anti-cancer, anti-inflammatory and anti-analgesic activity with large gastric tolerance. ${ }^{5,6}$ Some of these compounds are effective against alzheimer disease with very good $\mathrm{IC}_{50}$ values. $^{7}$ These compounds are also utilized as nonlinear optical materials, enzyme mimetics, selective membranes, ion-selective electrodes or sensors, chiral ligands in organometallic chemistry, synthetic precursors for the formation of spirans and sometimes, with some modifications, as high-performance liquid chromatography stationary phases. ${ }^{8,9}$ Literature studies revealed numerous methods to synthesize dibenzoxanthene derivatives, ${ }^{10-14}$ but very few reports have described $^{15-17}$ the synthesis of aryl-bis (2-hydroxy-1naphthyl) methane (4) and there are no reports for its keto isomer (3). Abbasi et al. synthesized bisnaphthols by adding conc. $\mathrm{HCl}$ to 2-naphthol and benzaldehyde in $\mathrm{AcOH}$ and then keeping the mixture for $50 \mathrm{~h}$ in a refrigerator to obtain a lower yield of product. ${ }^{18}$ Alizadeh

\footnotetext{
*For correspondence
}

et al. carried out the synthesis from 2-naphthol and aromatic aldehydes by refluxing dichloromethane using $\mathrm{H}_{3}\left[\mathrm{P}\left(\mathrm{Mo}_{3} \mathrm{O}_{10}\right)_{4}\right] \cdot n \mathrm{n}_{2} \mathrm{O}(\mathrm{HPA})$ as catalyst. ${ }^{19}$ Ohishi et al. developed a $\mathrm{TfOH}$ catalyzed condensation of phenols with aromatic aldehydes in ethanol as solvent at $3 \mathrm{kbar}$ pressure in $24 \mathrm{~h}$ at $60^{\circ} \mathrm{C} .{ }^{20}$ Many of these methods have their own limitations, such as longer reaction time, low yield and less product selectivity. Thus, these aspects have led us to search for new methodologies in mild condition with cheap and easily available heterogeneous or homogeneous Lewis acid catalysts for the synthesis of aryl-bis (2-hydroxy-1-naphthyl)methane (4) and its keto isomer (3).

\section{Experimental}

\subsection{General information}

All chemicals are commercially available and were used without further purification. ${ }^{1} \mathrm{H}$ and ${ }^{13} \mathrm{C}$ NMR spectra were recorded on a JEOL JNM ECS- $400 \mathrm{MHz}$ FT-NMR spectrometer in $\mathrm{CDCl}_{3}$ solution using TMS as internal standard. $J$-values are given in Hertz. IR spectra were recorded on a Nicolet Impact-410 spectrometer. The products were identified by comparison of their FT-IR, ${ }^{1} \mathrm{HNMR}$ and ${ }^{13} \mathrm{C}$ NMR spectroscopic data with those of authentic compounds and literature reported data. ${ }^{19-22}$ The elemental analysis were performed on Perkin Elmer 20-analyzer. Melting points were recorded in a Buchi B-540 melting point apparatus and were uncorrected. 

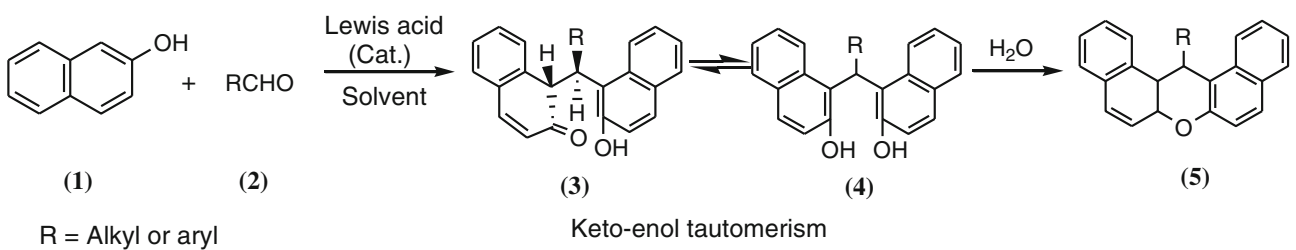

(3)

(4)

(5)

Scheme 1. Synthesis of keto isomer (3), bisnaphthol (4) and dibenzoxanthene (5) derivatives.

2.2 Typical procedure for the preparation of aryl-bis (2-hydroxy-1-naphthyl)methanes (4) and its keto isomers (3)

In a $50 \mathrm{~mL}$ round-bottomed flask, 2-naphthol( $2 \mathrm{mmol})$ and aldehyde $(1 \mathrm{mmol})$ were added in presence of catalysts $\mathrm{CuSO}_{4} \cdot 5 \mathrm{H}_{2} \mathrm{O}(10 \mathrm{~mol} \%)$ or $\mathrm{BF}_{3} . \mathrm{OEt}_{2}(28 \mathrm{~mol} \%)$ and acetic acid ( 2 drops). The entire mixture was then treated thermally at different temperatures in organic solvent $(3 \mathrm{~mL})$ or solvent-free condition for the specified reaction period. The progress of the reactions was monitored by observing TLC at certain intervals of time. After completion of the reaction, the mixture was diluted with ethyl acetate $(5 \mathrm{~mL})$ and filtered to remove the solid catalyst $\left(\mathrm{CuSO}_{4} .5 \mathrm{H}_{2} \mathrm{O}\right)$ which was not applicable for the $\mathrm{BF}_{3}$. $\mathrm{OEt}_{2}$ catalyzed reaction. The organic extract was dried over anhydrous $\mathrm{Na}_{2} \mathrm{SO}_{4}$ and distilled under reduced pressure to furnish the crude product. Further purification by preparative TLC yielded the pure product, which was analyzed by different spectroscopic techniques.

2.3 Selected spectral data of keto-enol intermediates (3)-(4) and dibenzoxanthene derivatives (5)

\section{3a Phenyl-bis-(2-hydroxy-1-naphthyl)methane}

(table 3, entry 1, (4a)): White solid; M.p. 203-205 ${ }^{\circ}$; FT-IR $(\mathrm{KBr}) \mathrm{cm}^{-1}:$ 3422, 2926, 2378, 1953, 1618, 1505, 1436, 1358, 1257, 1210, 1146, 1031, 957, 813, 749, 699; ${ }^{1} \mathrm{H} \mathrm{NMR}\left(\mathrm{CDCl}_{3}, 400 \mathrm{MHz}\right): \delta 7.91(\mathrm{~d}, J=$ $8.2 \mathrm{~Hz}, 2 \mathrm{H}), 7.8(\mathrm{~d}, J=8.2 \mathrm{~Hz}, 2 \mathrm{H}), 7.7(\mathrm{~d}, J=9.1 \mathrm{~Hz}$, 2H), 7.20-7.39 (m,9H), 7.01(d, $J=8.7 \mathrm{~Hz}, 2 \mathrm{H})$, $6.3(\mathrm{~s}, 1 \mathrm{H}) ;{ }^{13} \mathrm{C} \mathrm{NMR}\left(\mathrm{CDCl}_{3}, 100 \mathrm{MHz}\right): \delta 152.9,140.6$, 133.6, 130.1, 129.9, 129.7, 129, 128.4, 127.5, 123.6, 122.6, 119.9, 118.6, 42.7; CHN analysis (\%): $\mathrm{C}_{27} \mathrm{H}_{20} \mathrm{O}_{2}$ Cal. C 86.17, H 5.31; Found C 86.21, H 5.35.

2.3b 4-Nitrophenyl-bis-(2-hydroxy-1-naphthyl)methane (table 3, entry 4, $(\mathbf{4 d})$ ): Yellow solid; M.p. $145-147^{\circ} \mathrm{C}$; FT-IR (KBr) $\mathrm{cm}^{-1}:$ 3394, 2927, 2858, 2379, 2285, $1603,1511,1342,1257,1209,1147,954,811,743 ;{ }^{1} \mathrm{H}$ NMR $\left(\mathrm{CDCl}_{3}, 400 \mathrm{MHz}\right): \delta 8.06(\mathrm{~d}, J=6.9 \mathrm{~Hz}, 2 \mathrm{H})$, $7.92(\mathrm{~d}, J=8.2 \mathrm{~Hz}, 2 \mathrm{H}), 7.81(\mathrm{~d}, J=7.3 \mathrm{~Hz}, 2 \mathrm{H}), 7.68$ $(\mathrm{d}, J=8.2 \mathrm{~Hz}, 2 \mathrm{H}), 7.24-7.42(\mathrm{~m}, 7 \mathrm{H}), 6.98(\mathrm{~m}, 2 \mathrm{H})$; ${ }^{13} \mathrm{C} \mathrm{NMR}\left(\mathrm{CDCl}_{3}, 100 \mathrm{MHz}\right): \delta 152.2,150.4,146.5$, $135,130.3,129.3,128.6,127.7,123.9,123.7,122.2$, 119.3, 118.1, 42.2; $\mathrm{CHN}$ analysis (\%): $\mathrm{C}_{27} \mathrm{H}_{19} \mathrm{O}_{4} \mathrm{~N} \mathrm{Cal}$. C $76.95, \mathrm{H} 4.51, \mathrm{~N} 3.32$; Found C 77.10, H 4.55, N 3.36 .

2.3c 14-(4-Nitrophenyl)-14H-dibenzo[a.j]xanthene (table 3, entry 4, (5d)): Light yellow; M.p. 303$305^{\circ} \mathrm{C}$; FT-IR $(\mathrm{KBr}) \mathrm{cm}^{-1}$ : 3418, 2924, 2853, 2372, 2188, 1719, 1591, 1509, 1397, 1335, 1240, 1099, 952, 810, 741; ${ }^{1} \mathrm{H} \mathrm{NMR}\left(\mathrm{CDCl}_{3}, 400 \mathrm{MHz}\right): \delta 8.28(\mathrm{~d}, J=$ $8.2 \mathrm{~Hz}, 2 \mathrm{H}), 7.99(\mathrm{~d}, J=8.2 \mathrm{~Hz}, 2 \mathrm{H}), 7.81-7.85(\mathrm{~m}, 4 \mathrm{H})$, $7.65(\mathrm{~d}, J=8.3 \mathrm{~Hz}, 2 \mathrm{H}), 7.58(\mathrm{t}, J=7.8 \mathrm{~Hz}, 2 \mathrm{H}), 7.50$ $(\mathrm{d}, J=9.2 \mathrm{~Hz}, 2 \mathrm{H}), 7.40-7.44(\mathrm{~m}, 2 \mathrm{H}), 6.95(\mathrm{~s}, 1 \mathrm{H}) ;{ }^{13} \mathrm{C}$ NMR $\left(\mathrm{CDCl}_{3}, 100 \mathrm{MHz}\right): \delta 152,148.9,146.4,131.1$, $129.7,129.1,129,127.3,124.7,123.9,122.1,118.1$, 116, 37.9; $\mathrm{CHN}$ analysis (\%): $\mathrm{C}_{27} \mathrm{H}_{17} \mathrm{O}_{3} \mathrm{~N}$,Cal. C 80.39,H 4.21 ,N 3.47; Found C 80.43, H 4.24 , N 3.51.

2.3d 14-(4-Methylphenyl)-14H-dibenzo [a.j]xanthene (table 3, entry-6, (5f)): Yellow solid; M.p. $227-228^{\circ} \mathrm{C}$; FT-IR $(\mathrm{KBr}) \mathrm{cm}^{-1}$ : 3068, 2917, 1626, 1597, 1515, 1466, 1437, 1404, 1258, 1125, 1087, 967, 840, 815, 785,$745 ;{ }^{1} \mathrm{H}$ NMR $\left(\mathrm{CDCl}_{3}, 400 \mathrm{MHz}\right): \delta 7.69-7.78(\mathrm{~m}$, $3 \mathrm{H}), 7.36(\mathrm{~d}, J=7.8 \mathrm{~Hz}, 3 \mathrm{H}), 7.27(\mathrm{t}, J=6.9 \mathrm{~Hz}$, $1 \mathrm{H}), 7.13-7.16(\mathrm{~m}, 6 \mathrm{H}), 6.91(\mathrm{t}, J=7.3 \mathrm{~Hz}, 1 \mathrm{H}), 6.77$ $(\mathrm{d}, J=7.8 \mathrm{~Hz}, 2 \mathrm{H}), 6.14(\mathrm{~s}, 1 \mathrm{H}), 2.3(\mathrm{~s}, 3 \mathrm{H}) ;{ }^{13} \mathrm{C} \mathrm{NMR}$ $\left(\mathrm{CDCl}_{3}, 100 \mathrm{MHz}\right): \delta 156,146.5,138.4,130,129.9$, 129.4, 129.1, 128.9, 127.9, 126.8, 122.8, 121.4, 199.9, 116.5, 11.8, 62.7, 21.1;CHN analysis $(\%): \mathrm{C}_{28} \mathrm{H}_{20} \mathrm{O}$, Cal. C 90.32, H 5.37; Found C 90.37, H 5.40.

2.3e 4-chlorophenyl-(2-hydroxy-1-naphthyl)(benzocyclohex3-en-2-one)methane (New) (table 3, entry 6, (3e)): Red solid; M.p. $243-245^{\circ}$ C; FT- IR (KBr) $\mathrm{cm}^{-1}$ : $3425,2917,3050,2851,1677,1624,1465,1383$, 1256, 1205, 1089, 1024, 939, 813, 747; ${ }^{1} \mathrm{H}$ NMR $\left(\mathrm{CDCl}_{3}, 400 \mathrm{MHz}\right): \delta 7.87(\mathrm{~d}, 1 \mathrm{H}, J=8.7 \mathrm{~Hz}), 7.82$ (d, $1 \mathrm{H}, J=8.3 \mathrm{~Hz}), 7.44-7.15(\mathrm{~m}, 13 \mathrm{H}), 6.91(\mathrm{~d}, 1 \mathrm{H}$, 
Table 1. Optimization of the reaction using homogeneous and heterogeneous Lewis acid catalysts.

\begin{tabular}{|c|c|c|c|c|c|c|}
\hline Entry & $\begin{array}{l}\text { Catalyst } \\
\text { (Promoter) }\end{array}$ & $\begin{array}{l}\text { Catalyst } \\
(\mathrm{mol} \%)^{\mathrm{b}}\end{array}$ & Solvent & $\begin{array}{l}\text { Temp } \\
\left({ }^{\circ} \mathrm{C}\right)\end{array}$ & $\begin{array}{l}\text { Time } \\
\text { (h) }\end{array}$ & $\begin{array}{l}\text { (\%) Yield } \\
\underline{\mathbf{4 a})}\end{array}$ \\
\hline 1 & $\mathrm{FeSO}_{4} .7 \mathrm{H}_{2} \mathrm{O} / \mathrm{CuSO}_{4} .5 \mathrm{H}_{2} \mathrm{O}$ & 10 & - & 120 & 4 & $40 / 50$ \\
\hline 2 & $\mathrm{FeSO}_{4} .7 \mathrm{H}_{2} \mathrm{O} / \mathrm{CuSO}_{4} .5 \mathrm{H}_{2} \mathrm{O}$ & 10 & $\mathrm{MeOH}$ & 65 & 7 & 38/95 \\
\hline 3 & $\mathrm{CuSO}_{4} .5 \mathrm{H}_{2} \mathrm{O}$ & $5 / 10 / 25$ & $\mathrm{EtOH}$ & 78 & 7 & $50 / 70 / 72$ \\
\hline 4 & $\mathrm{CuSO}_{4} .5 \mathrm{H}_{2} \mathrm{O}$ & 10 & THF/MeCN/Acetone & $66 / 82 / 57$ & 4 & NR/20/NR \\
\hline 5 & $\mathrm{CuSO}_{4} .5 \mathrm{H}_{2} \mathrm{O}$ & 10 & $\begin{array}{l}\mathrm{H}_{2} \mathrm{O} / \mathrm{EtOH}: \mathrm{H}_{2} \mathrm{O} \\
(1: 1) / \mathrm{C}(\mathrm{Me})_{3} \mathrm{OH}\end{array}$ & $100 / 100 / 83$ & 7 & $45 / 18 / \mathrm{NR}$ \\
\hline 6 & $\mathrm{BF}_{3} \cdot \mathrm{OEt}_{2}$ & 28 & $\mathrm{CH}_{2} \mathrm{Cl}_{2}$ & r.t. ${ }^{\mathrm{c}}$ & 4 & 50 \\
\hline 7 & $\mathrm{BF}_{3} \cdot \mathrm{OEt}_{2}(\mathrm{AcOH})^{\mathrm{a}}$ & 28 & $\mathrm{CH}_{2} \mathrm{Cl}_{2}$ & r.t $/ 65$ & $1 / 2.2$ & $85 / 60$ \\
\hline 8 & $\mathrm{BF}_{3} \cdot \mathrm{OEt}_{2}(\mathrm{AcOH})$ & 10 & $\mathrm{CH}_{2} \mathrm{Cl}_{2}$ & r.t. & 1 & 40 \\
\hline 9 & $\mathrm{BF}_{3} \cdot \mathrm{OEt}_{2}(\mathrm{AcOH})$ & 28 & $\begin{array}{c}\mathrm{EtOH} / \mathrm{MeOH} / \\
\mathrm{H}_{2} \mathrm{O} / \mathrm{THF} / \mathrm{CH}_{3} \mathrm{CN}\end{array}$ & r.t. & 2 & 10/15/NR/NR/NR \\
\hline 10 & $\mathrm{BF}_{3} \cdot \mathrm{OEt}_{2}$ & 28 & $\mathrm{AcOH}$ & r.t. & 2 & 80 \\
\hline 11 & $\mathrm{AcOH}(2$ drops $)$ & - & $\mathrm{CH}_{2} \mathrm{Cl}_{2}$ & ', & 12 & NR \\
\hline 12 & $\mathrm{BF}_{3}-\mathrm{SiO}_{2}$ & 28 & $\mathrm{CH}_{2} \mathrm{Cl}_{2}$ & '” & $12 \mathrm{~h}$ & NR \\
\hline 13 & $\mathrm{BF}_{3}-\mathrm{SiO}_{2}$ ( 2 drops $)$ & 28 & $\mathrm{CH}_{2} \mathrm{Cl}_{2}$ & ‘ & $12 \mathrm{~h}$ & 20 \\
\hline
\end{tabular}

${ }^{\mathrm{a}}$ Using 2-drops of AcOH as promoter, ${ }^{\mathrm{b}}$ Reactions were carried out with 2 mmol of 2-naphthol and 1 mmol of aldehydes, ${ }^{\mathrm{c}}$ Room temperature

$J=7.8 \mathrm{~Hz}), 5.55(\mathrm{~d}, 1 \mathrm{H}, J=10.1 \mathrm{~Hz}), 5.12(\mathrm{~s}, 1 \mathrm{H})$; ${ }^{13} \mathrm{C}$ NMR $\left(\mathrm{CDCl}_{3}, 100 \mathrm{MHz}\right): \delta 198.7,158.7,143.8$, $143.7,136.7,133.9,131.3,130.9,130.5,130.4,129.6$, 129.1, 128.9, 127.0, 125.5, 125.1, 123.4, 122.7, 117.2, 112.0, 64.0, 29.78.CHN analysis (\%): $\mathrm{C}_{27} \mathrm{H}_{19} \mathrm{O}_{2} \mathrm{Cl}$, Cal. C 78.92, H 4.62; Found C 79.10, H 4.68.

The COSY and DEPT spectra are included in figure 2 and supplementary file respectively. In ${ }^{1} \mathrm{H}$ NMR, the $\mathrm{OH}$ proton was not observed.

2.3f 4-methylphenyl-(2-hydroxy-1-naphthyl)(benzocyclohex3-en-2-one)methane (New) (table 3, entry 5, (3f)): red solid; M.p. 204-208 ${ }^{\circ}$; FT IR (KBr): 3408, 3049, 2919, 2853, 1683, 1623, 1511, 1457, 1380, 1256, 1112 , 1024, 946, 810, $746 \mathrm{~cm}^{-1} ;{ }^{1} \mathrm{H} \mathrm{NMR}\left(\mathrm{CDCl}_{3}, 400 \mathrm{MHz}\right)$ : $\delta 7.88(\mathrm{~d}, 1 \mathrm{H}, J=8.7 \mathrm{~Hz}), 7.83(\mathrm{~d}, 1 \mathrm{H}, J=7.8 \mathrm{~Hz})$, $7.14-7.47(\mathrm{~m}, 13 \mathrm{H}), 6.92(\mathrm{~d}, 1 \mathrm{H}, J=7.7 \mathrm{~Hz}), 5.55$ $(\mathrm{d}, 1 \mathrm{H}, J=10.1 \mathrm{~Hz}), 5.16(\mathrm{~s}, 1 \mathrm{H}), 2.25(\mathrm{~s}, 3 \mathrm{H}) ;{ }^{3} \mathrm{C}$ $\operatorname{NMR}\left(\mathrm{CDCl}_{3}, 100 \mathrm{MHz}\right): \delta 198.6,158.6,144.0,143.3$, 137.6, 135.1, 130.9, 130.3, 129.4, 129.0, 128.6, 126.7, $125.6,124.9,123.2,122.9,117.9,112.0,64.5,29.7$,
21.2, $\mathrm{CHN}$ analysis (\%): $\mathrm{C}_{28} \mathrm{H}_{22} \mathrm{O}_{2}$, Cal. C 86.15, H 5.64; Found C 86.21, H 5.68.

The COSY and DEPT spectra are included in figure 2 and supplementary files respectively. In ${ }^{1} \mathrm{H}$ NMR, the $-\mathrm{OH}$ proton was not observed.

\section{Results and Discussions}

Initially, we screened the catalytic activity of three Lewis acids $\mathrm{FeSO}_{4} \cdot 7 \mathrm{H}_{2} \mathrm{O}, \mathrm{CuSO}_{4} .5 \mathrm{H}_{2} \mathrm{O}$ and $\mathrm{BF}_{3} . \mathrm{OEt}_{2}$ (table 1) in solution (or solvent-free) at different temperatures with the model reaction of benzaldehyde (1 mmol) and 2-naphthol $(2 \mathrm{mmol})$ for the synthesis of aryl-bis (2-hydroxy-1-naphthyl)methane (4a). We observed better result with $10 \mathrm{~mol} \%$ of $\mathrm{CuSO}_{4} \cdot 5 \mathrm{H}_{2} \mathrm{O}$ in methanol under reflux condition (table 1 , entry 2 ). The weak acid-base interaction of smaller size methanol and $\mathrm{CuSO}_{4} .5 \mathrm{H}_{2} \mathrm{O}$ may activate some solvent molecules to form H-bonds with the carbonyl group of aldehyde molecule for nucleophilic attack of 2-naphthol. Such types of activation will be less effective using

Table 2. Comparison of the results obtained for the preparation of $\mathbf{4 a}$ and $\mathbf{5} \mathbf{a}$ using other catalysts.

\begin{tabular}{|c|c|c|c|c|c|c|}
\hline \multirow[b]{2}{*}{ Entry } & \multirow[b]{2}{*}{ Catalyst } & \multirow[b]{2}{*}{ Conditions } & \multirow[b]{2}{*}{ Time (h) } & \multicolumn{2}{|c|}{ Yields $(\%)$} & \multirow[b]{2}{*}{ References } \\
\hline & & & & $\underline{\mathbf{4 a}}$ & $\underline{5 a}$ & \\
\hline 1 & $\mathrm{BF}_{3} \cdot \mathrm{SiO}_{2}$ & Solvent-free $/ 60^{\circ} \mathrm{C}$ & 0.25 & - & 96 & 21 \\
\hline 2 & $\mathrm{BF}_{3} \cdot \mathrm{SiO}_{2}$ & Chloroform/r.t & 24 & - & - & 21 \\
\hline 3 & $\mathrm{BF}_{3} \cdot \mathrm{SiO}_{2}$ & Sonication/reflux in $\mathrm{CHCl}_{3}$ & $6 \mathrm{~min}$ & - & 95 & 21 \\
\hline 4 & $\mathrm{BF}_{3} . \mathrm{SiO}_{2} / \mathrm{AcOH}$ & $\mathrm{CH}_{2} \mathrm{Cl}_{2} / \mathrm{r} . \mathrm{t}$ & 12 & 20 & - & Present method \\
\hline 5 & $\mathrm{BF}_{3} \cdot \mathrm{OEt}_{2} / \mathrm{AcOH}$ & $\mathrm{CH}_{2} \mathrm{Cl}_{2} / \mathrm{r} . \mathrm{t}$ & 1 & 85 & - & " 6 \\
\hline 6 & $\mathrm{H}_{3}\left[\mathrm{P}\left(\mathrm{Mo}_{3} \mathrm{O}_{10}\right)_{4}\right]-\mathrm{nH}_{2} \mathrm{O}$ & $\mathrm{CH}_{2} \mathrm{Cl}_{2} / 40^{\circ} \mathrm{C}$ & 1 & 51 & - & 19 \\
\hline 7 & Conc. $\mathrm{HCl}$ in $\mathrm{AcOH}$ & $0^{\circ} \mathrm{C}$ & 50 & 64 & - & 18 \\
\hline 8 & $\mathrm{TfOH}$ & $\mathrm{EtOH} / 3 \mathrm{kbar}, 60^{\circ} \mathrm{C}$ & 24 & 89 & - & 20 \\
\hline
\end{tabular}




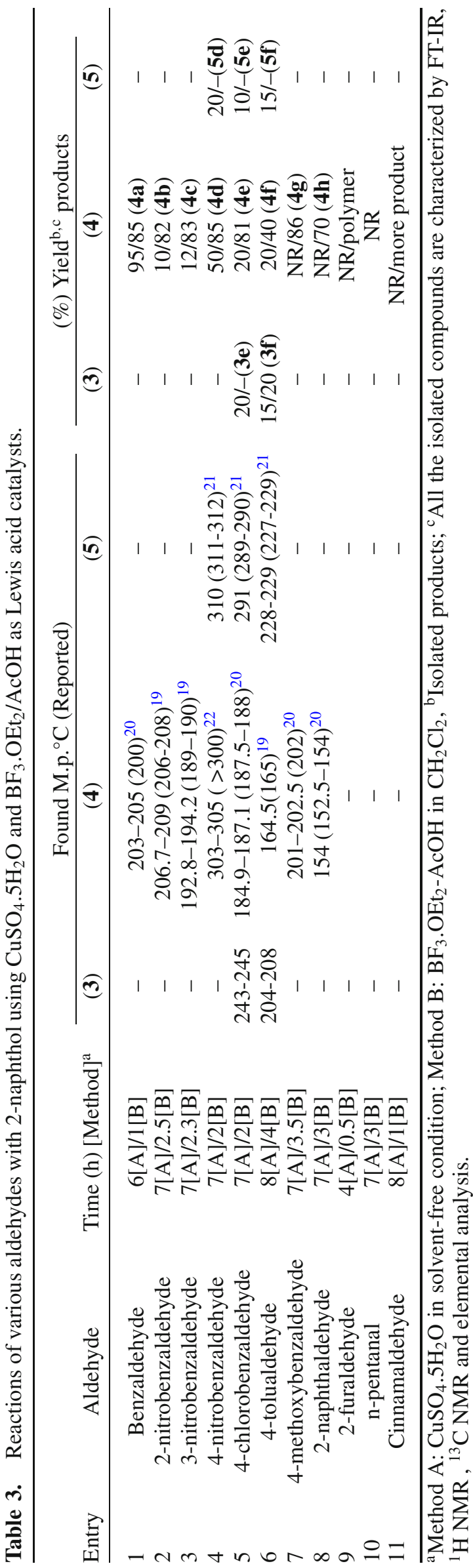

bulkier size alcohol as reaction medium like ter-butanol (table 1 , entry 5). The use of $\mathrm{BF}_{3} \cdot \mathrm{OEt}_{2}$ catalyst alone gave poor result (table 1, entry 6) as compared to its combination with $\mathrm{AcOH}$ as promoter (table 1, entry 7). The optimized condition utilized $0.28 \mathrm{mmol}$ of $\mathrm{BF}_{3} . \mathrm{OEt}_{2}$ and 2 drops of $\mathrm{AcOH}$ in dichloromethane at room temperature for $1 \mathrm{~h}$ time (table 1, entry 7 ). Use of acetic acid as reaction medium completed the reaction within $2 \mathrm{~h}$ with good yield of product using $0.28 \mathrm{mmol} \mathrm{BF}_{3} . \mathrm{OEt}_{2}$ (table 1, entry 10 ). No reaction occurred up to $12 \mathrm{~h}$ reaction time with 2 drops of $\mathrm{AcOH}$ in dichloromethane at room temperature stirring (table 1, entry 11). This observation indirectly supported the role of $\mathrm{AcOH}$ as promoter for the synthesis of bisnaphthol derivatives. We also tried to synthesize bisnaphthol 4a in solution with $\mathrm{BF}_{3} \cdot \mathrm{SiO}_{2}$ as heterogeneous catalysts (table 1, entries 12). ${ }^{21}$ The combination of acetic acid and $\mathrm{BF}_{3}$-silica produced only $20 \%$ of 4a under optimized condition during $12 \mathrm{~h}$ (table 1, entry 13 ).

The efficiency and applicability of the present methods for the synthesis of $\mathbf{4 a}$ and $\mathbf{5 a}$ have been compared with some of the previously known methods in table 2 .

After standardizing the reaction conditions, we extended these studies with different aromatic and aliphatic aldehydes to synthesize aryl-bis (2-hydroxy1-naphthyl) methanes (4) and its keto isomers (3). All these results are tabulated in table 3 .

The observations in table 3 clearly expressed the non-selective behaviour of $\mathrm{CuSO}_{4} .5 \mathrm{H}_{2} \mathrm{O}$ catalyst with aromatic aldehydes under reflux condition in methanol except benzaldehyde molecule (table 3 , entry 1 ) which gave bisnaphthol (4a) as a single product. With $p$-nitro benzaldehyde, we got diol (4d) as major and dibenzoxanthene (5d) as minor products (table 3, entry 4) while $o$ - and $m$-nitro benzaldehydes selectively yielded diols $(\mathbf{4 b}, \mathbf{4 c})$ as minor products (table 3, entries 2-3). For the first time, it was possible to isolate the keto intermediates $(\mathbf{3 e}, \mathbf{3 f})$ from the reaction mixtures of 4-chlorobenzaldehyde and $p$-tolualdehyde along with diol (4) and dibenzoxanthene derivatives (5) using

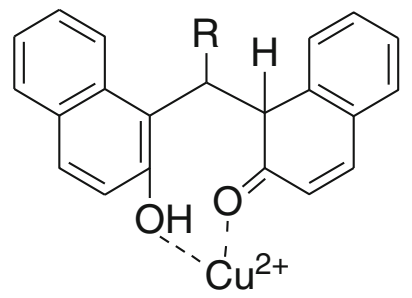

(3)

Figure 1. Stable complexion of $\mathrm{Cu}^{2+}$ with the keto-isomer (3). 


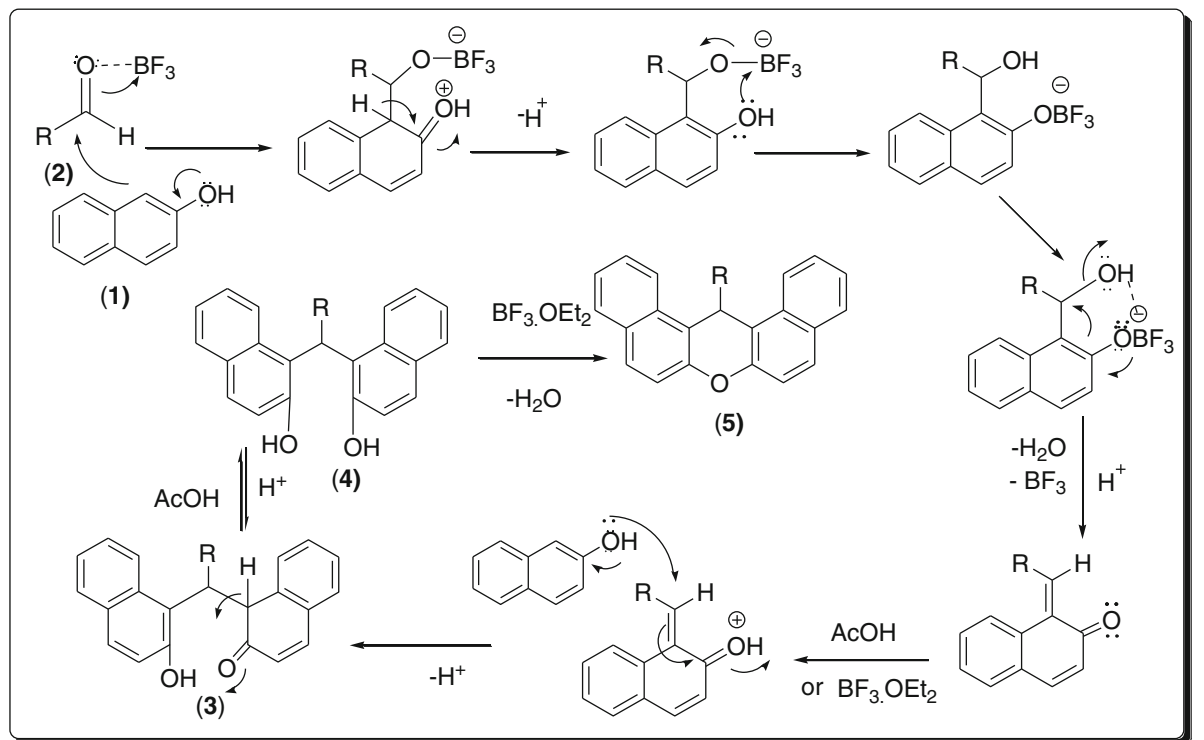

Scheme 2. Plausible mechanism.

$\mathrm{CuSO}_{4} .5 \mathrm{H}_{2} \mathrm{O}$ as catalyst (table 3 , entries 5-6). The $\mathrm{BF}_{3} \cdot \mathrm{OEt}_{2}-\mathrm{AcOH}$ catalyst produced diol (4) selectively from aromatic aldehydes in dichloromethane at ambient temperature with excellent yields during short time (table 3, entries 1-5, 7) except $p$-tolualdehyde (table 3, entry 6). The reaction of $p$-tolualdehyde showed the equilibrium mixture of keto and enol forms in solution (table 3, entry 6). 2-Naphthaldehyde yielded only 70\% of diol in $3 \mathrm{~h}$ with $\mathrm{BF}_{3} \cdot \mathrm{OEt}_{2}-\mathrm{AcOH}$ catalyst (table 3 , entry 8). Pentanal was inactive in both cases during 3-7 h reaction times (table 3 , entry 10 ). Under the reaction conditions of $\mathrm{BF}_{3} \cdot \mathrm{OEt}_{2}-\mathrm{AcOH}, 2$-Furaldehyde polymerized and cinamaldehyde produced more side products (table 3, entries 9, 11). The reaction of 1-naphthol and benzaldehyde also generated many products with $\mathrm{BF}_{3} \cdot \mathrm{OEt}_{2}-\mathrm{AcOH}$ catalyst.

During the isolation of the keto intermediate $(\mathbf{3 e}-$ 3f) by preparative TLC technique, we obtained a single product in dichloromethane at $25^{\circ} \mathrm{C}$. But after distillation at $50^{\circ} \mathrm{C}$ in vacuum, it decomposed to diol (4e-4f) almost in equal proportion. The FTIR spectra of the product mixture of $(\mathbf{4 e - 4 f})$ indicated characteristics - $\mathrm{OH}$ absorption in the range of $3400-3428 \mathrm{~cm}^{-1}$, strong carbonyl absorption at $1657-$ $1670 \mathrm{~cm}^{-1}$ which clearly indicated the existence of keto-enol tautomer's at high temperature. We isolated the keto product in pure form after removal of the organic solvent under reduced pressure at room temperature. With increasing temperature, the keto intermediate slowly converted to the diol through ketoenol equilibrium (scheme 1) for the reaction of 4chlorobenzaldehyde and $p$-tolualdehyde. The simultaneous acid-base complexion of $\mathrm{CuSO}_{4} .5 \mathrm{H}_{2} \mathrm{O}$ catalyst (figure 1) with the carbonyl and $-\mathrm{OH}$ groups of the keto-isomer (3) may stabilize this intermediate as compared to $\mathrm{BF}_{3} \cdot \mathrm{OEt}_{2} /$ acetic acid according to the plausible mechanism of $\mathrm{BF}_{3} \cdot \mathrm{OEt}_{2} /$ acetic acid (scheme 2).

The COSY spectra of keto compounds (3e-3f) have no cross-peak for the two tertiary 1,2-protons in the
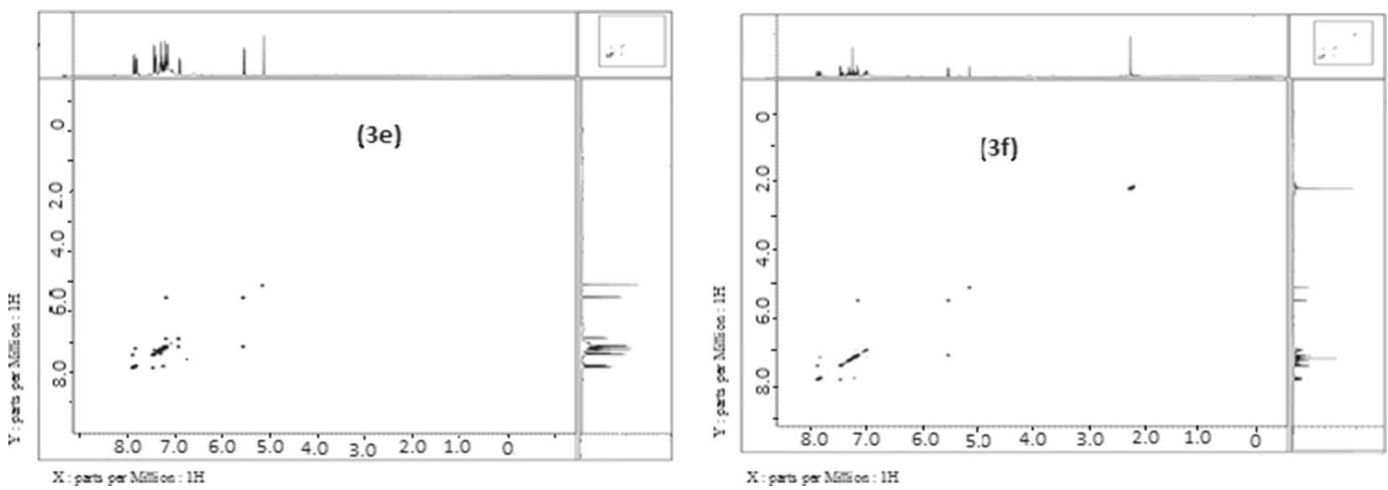

Figure 2. COSY spectra of (3e) and (3f). 
chemical shift range of $\delta 5.12-5.16(\mathrm{~s})$ and 5.55(d) ppm which confirm the anti-orientation of these protons in (3) (figure 2). But the proton with doublet at 5.55 ppm for the tertiary methane group has one cross peak with the aromatic region by long range coupling constant $J=10.1 \mathrm{~Hz}$ of the $o$-proton of 4-chloro phenyl ring. The DEPT-45 spectra have all the methane (-CH-) and methyl carbons except the quaternary carbons. In DEPT-90 spectra, all - $\mathrm{CH}$ - signals are present in normal positions. The DEPT-135 spectra of the keto isomers are identical with the DEPT- 45 spectra which confirm the exact structure of the keto intermediate (see Supplementary Information).

\section{Conclusion}

The existence of keto-enol mechanism was fully supported by the isolation of two reactive keto intermediates in the synthesis of aryl-bis(2-hydroxy-1naphthyl)methanes (4) and its cyclization product dibenzoxanthenes (5) for the first time. Furthermore, this study developed a new catalytic system for the selective synthesis of bisnaphthol derivatives under mild condition using $\mathrm{BF}_{3}$. $\mathrm{OEt}_{2}-\mathrm{AcOH}$ as homogeneous catalyst. The silica supported $\mathrm{BF}_{3}$ was almost inactive under the reaction condition using $\mathrm{AcOH}$ as promoter.

\section{Supplementary Information}

The selected NMR spectra $\left({ }^{1} \mathrm{H}\right.$ NMR, ${ }^{13} \mathrm{C}$ NMR and DEPT) of keto-enol intermediates (3)-(4) and dibenzoxanthene derivatives (5) are included in the supplementary file. Supplementary information is available at www.ias.ac.in/chemsci.

\section{Acknowledgement}

The authors are thankful to Sophisticated Analytical Instrumentation Centre, Tezpur University, for analyses of various samples for this work.

\section{References}

1. Wang X-Z, Yang B-Y, Lin G-J, Xie Y-Y, Huang H-L and Liu Y-J 2012 DNA and Cell Biology 311468

2. Bhowmik B B and Ganguly P 2005 Spectrochim Acta Part A 611997

3. Knight C G and Stephens T 1989 Biochem. J. 258 683

4. Ahmad M, King T A, Ko D-K, Cha B H and Lee J 2002 J. Phys. D Appl. Phys. 351473

5. Lacroix R, Arbeille B, Armaing C, Lacroix $\mathrm{J}$ and Reynouard F 1985 Ann. Pharm. Fr. 43479

6. Poupelin J P 1979 Anti-inflammatory and analgesic medicaments US Patent No.4147806, April 3

7. Colombo L, Piovesan P, Ghirardi O, Salmona M and Forloni G 2009 Arch. Virol. 1541539

8. Vries J G D and Lefort L 2006 Chem. Eur. J. 12 4722

9. Handique J G and Barauh J B 2002 React. Funct. Polym. 52163

10. Kumar A, Sharma S, Maurya R A and Sarkar J 2010 J. Comb. Chem. 1220 and references cited therein

11. Shaterian H R and Ghashang M 2008 J. Braz. Chem. Soc. 191053

12. Zare-Bidaki A and Davoodnia A 2012 Bull. Korean Chem. Soc. 331154

13. Das B, Kumar D N, Laxminarayana K and Ravikanth B 2007 Helvetica Chimica Acta 901330

14. Mokhtary M and Refahati S 2013 Dyes and Pigments 99 378 and references cited therein

15. Kharasch M S and Marker R 1926 J. Am. Chem. Soc. 48 3130

16. Poupelin J P, Saint-Ruf G, Lacroix R , Narcisse G, Foussard-Blampin O and Uchida-Ernouf G 1978 Eur. J. Med. Chem. Ther. 3381

17. Khoramabadi-zad A, Kazemi Z and Rudbari H A 2002 J. Korean Chem. Soc. 466

18. Ranjbar P R, Abbasi A, Vafakisha B and Fischer A 2007 Acta. Cryst. E 63 o2093-o2094

19. Alizadeh A, Khodaei A A and Moradi K H 2010 J. Iran. Chem. Soc. 7351

20. Ohishi T, Kojima T, Matsuoka T, Shiro $M$ and Kotsuki H 2001 Tetra. Lett. 422493 and references cited therein

21. Mirjalili B B F, Bamoniri A and Akbari A 2008 Tetra. Lett. 496454

22. Kasturi T R, Kumar K A and Pragnacharyulu P V P 1993 Tetrahedron 49125 and references cited therein 